\title{
RESPONS PEMBERIAN BERBAGAI DOSIS MOL DAUN KELOR DENGAN PENAMBAHAN KULIT BUAH PISANG TERHADAP PERTUMBUHAN DAN HASIL TANAMAN JAGUNG MANIS
}

\section{GIVING RESPONSE OF VARIOUS DOSAGE OF KELOR LEAF MOLL WITH ADDITION OF BANANA FRUIT LEATHER TO GROWTH AND RESULTS OF SWEET CORN PLANTS}

\author{
Kurniawan Dj. Laepo ${ }^{1}$, Aris Aksarah Pas ${ }^{{ }^{*}}$, Idris ${ }^{1}$ \\ ${ }^{1}$ Program Studi Agroteknologi, Fakultas Pertanian Universitas Alkhairaat Palu, \\ Jl. Diponegoro No. 39 Palu 94221, Indonesia
}

\begin{abstract}
ABSTRAK
Penelitian ini bertujuan untuk mempelajari dan mengetahui pengaruh pemberian berbagai dosis Mol daun kelor dengan penambahan kulit buah pisang terhadap pertumbuhan dan hasil tanaman jagung manis (Zea mays saccharata Sturt.) karena melihat bahwa pengembangan pertanian yang ramah lingkungan merupakan keharusan demi kelangsungan produksi dan kesehatan. Upaya-upaya tersebut telah direkomendasikan oleh pemerintah, salah satu usaha yang dilakukan adalah dengan melakukan usaha pertanian secara organik, Penelitian ini dilaksanakan di Kelurahan Kalukubula Kecamatan Dolo Kabupaten Sigi Provinsi Sulawesi Tengah. Penelitian ini menggunakan Rancangan Acak Kelompok (RAK) satu faktor, pengelompokan dilakukan berdasarkan arah datangnya sinar matahari dengan perlakuan berbagai dosis MOL daun kelor dengan penambahan kulit buah pisang. Adapun perlakuan yang dicobakan terdiri dari 4 taraf yaitu : $\mathrm{PM}_{0}$ : Tanpa MOL (Kontrol), $\mathrm{PM}_{1}: 200 \mathrm{ml}+2$ liter air/ petak, $\mathrm{PM}_{2}: 400 \mathrm{ml}+2$ liter air/ petak, $\mathrm{PM}_{3}: 600 \mathrm{ml}+2$ liter air/ petak. Setiap perlakuan yang dicobakan diulang sebanyak tiga (3) kali, maka terdapat $3 \times 4=12$ unit percobaan. Untuk mengetahui pengaruh perlakuan yang dicobakan pada tanaman, dilakukan analisis ragam dan perlakuan berpengaruh nyata dilanjutkan dengan uji BNJ $\alpha=0,05$. Hasil penelitian menunjukkan bahwa respons berbagai dosis Mol dun kelor dengan penambahan kulit buah pisang terhadap pertumbuhan dan hasil tanaman jagung manis pada pengamatan jumlah daun, lingkar batang, umur berbungan, panjang tongkol, lingkar tongkol, berat tongkol $(\mathrm{g})$, berat tongkol per petak $(\mathrm{kg})$ dan berat tongkol per hektar (t) tidak berpengaruh nyata, sedangakan perlakuan Mol daun kelor dengan penambahan kulit buah pisang dengan dosis $600 \mathrm{ml}+200$ liter air $\left(\mathrm{PM}_{3}\right)$ berpengaruh nyata pada tinggi tanaman pada umur 15, 30 dan $45 \mathrm{HST}(28,70,52,15$ dan 96,28) dan panjang daun pada umur 15, 30 dan 45 HST $(20,14,41,07$ dan 67,32) pada tanaman jagung manis.
\end{abstract}

Katakunci: MOL, daun kelor, jagung manis

\section{ABSTRACT}

This study aims to study and determine the effect of various doses of Moringa leaf Mole by adding banana peels to the growth and yield of sweet corn plants (Zea mays saccharata Sturt.) Because they see that the development of environmentally friendly agriculture is a must for the continuity of production and health. These efforts have been recommended by the government, one of the efforts made is to conduct an organic farming business. This research was carried out in the Kalukubula Sub-District, Dolo District, Sigi Regency, Central Sulawesi Province. This study used a one-factor randomized block design $(R B D)$, grouping was done based on the direction of the arrival of sunlight by treating various doses of MOL Moringa leaves with the addition of banana peels. The treatment tried consisted of 4 levels, namely: PM0: No MOL (Control), PM1: $200 \mathrm{ml}+2$ liters of water / plot, PM2: $400 \mathrm{ml}+2$ liters of water / plot, PM3: $600 \mathrm{ml}+2$ liters of water / plot . Each treatment that was tried was repeated three (3) times, then there were $3 \times 4=12$ experimental units. To determine the effect of the treatment that was tried on plants, a variety of analyzes and treatments were carried out which significantly affected followed by a BNJ test $\alpha=0.05$. The results showed that the response of various doses of mole dun moringa with the addition of banana peels to the growth and yield of sweet corn on observing the number of leaves, stem 
e-ISSN : 2621-7236

Jurnal Ogrotech 9 (1) 12-18

p-ISSN : 1858-134X

circumference, mixed age, ear length, ear circumference, ear weight $(g)$, ear weight per plot ( $\mathrm{kg})$ and weight of ear per hectare ( $t$ ) did not have a significant effect, while the treatment of Moringa leaf Mole with the addition of banana peels at a dose of $600 \mathrm{ml}+200$ liters of water (PM3) significantly affected plant height at 15, 30 and 45 HST $(28,70,52.15$ and 96.28) and the length of leaves at the ages of 15, 30 and $45 \operatorname{HST}(20,14,41,07$ and 67,32) in sweet corn plants.

Keywords: MOL, Moringa leaves, sweet corn

\section{Pendahuluan}

Keberhasilan pemerintah berswasembada beras tidak menjamin terbentuk ketahanan pangan yang permanen. Terbukti saat ini telah diberlakukan kebijakan impor beras untuk memenuhi komsumsi dalam negeri. Hal inilah yang mendorong perlu adanya upaya diversifikasi pangan dengan tidak berfokus pada pengusaha padi semata tetapi juga komoditas lain yang dapat dijadikan sebagai alternatif bahan pangan seperti jagung, umbi-umbian, sagu dan jenis pangan lainnya.

Komoditi pangan yang popular selain padi dan gandum adalah jagung. Jagung juga dikembangkan untuk memenuhi kebutuhan pangan masyarakat. Jagung adalah salah satu sumber makanan yang sangat baik karena mengandung $80 \%$ karbohidrat, $10 \%$ protein, 4,5\% minyak dan 2\% mineral (Agitarani, 2011). Sendangkan menurut Harahap (2007) menyebutkan bahwa, jagung mengandung $77 \%$ pati, $2 \%$ gula, $9 \%$ protein, $5 \%$ pentosan serta $2 \%$ bahan-bahan yang mengandung unsur $\mathrm{Ca}, \mathrm{Mg}$, $\mathrm{P}, \mathrm{Al}, \mathrm{Fe}, \mathrm{Na}$ dan $\mathrm{Cl}$, dengan adanya komposisi ini maka jagung bernilai sangat baik untuk dikonsumsi. Jagung yang saat ini dikenal masyarakat ada beberapa jenis yaitu jagung lokal, jagung manis, jagung pulut/ketan dan jagung pulut manis.

Jagung manis (Zea mays saccharata Sturt.) dikenal dengan nama Sweet Corn banyak dikembangkan di Indonesia. Jagung manis banyak dikonsumsi karena memiliki rasa yang lebih manis, aroma lebih harum dan mengandung gula sukrosa serta rendah lemak sehingga baik dikonsumsi bagi penderita diabetes (Putri, 2011).

Pengembangan pertanian yang ramah lingkungan merupakan keharusan demi kelangsungan produksi dan kesehatan. Upayaupaya tersebut telah direkomendasikan oleh pemerintah, salah satu usaha yang dilakukan adalah dengan melakukan usaha pertanian secara organik. Pertanian organik merupakan suatu sistem untuk mengembalikan semua jenis bahan

\footnotetext{
${ }^{*)}$ Penulis Korespondensi

E-mail: pasarisaksarah@yahoo.co.id

Telp: +62-81341012887
}

organik ke dalam tanah, baik dalam bentuk limbah pertanian, limbah rumah tangga maupun limbah peternakan, yang selanjutnya bertujuan untuk memberi makanan pada tanaman untuk bertumbuh dengan baik (Herniwati dan Nappu, 2011).

Salah satu upaya yang dilakukan dalam usahatani tanpa menggunakan bahan - bahan kimia yang akan merusak lingkungan adalah dengan penggunaan mikroorganisme lokal (MOL). Penyubur tanaman memanfaatkan mikroorganisme lokal menjadi solusi bagi petani lokal, menuju pertanian ramah lingkungan dan bebas dari pupuk dan obat-obatan kimiawi. Bahan MOL mudah didapatkan di Indonesia dan mudah diolah.

MOL adalah mikroorganisme yang dimanfaatkan sebagai starter dalam pembuatan pupuk organik padat maupun pupuk cair. Adapun bahan utama MOL terdiri dari beberapa komponen, yaitu karbohidrat, glukosa dan sumber mikroorganisme. Bahan dasar untuk fermentasi larutan MOL dapat berasal dari hasil pertanian, perkebunan, maupun limbah organik rumah tangga (Purwasasmita, 2009).

Karbohidrat sebagai sumber nutrisi untuk mikroorganisme dapat diperoleh dari limbah organik, seperti air cucian beras, singkong, gandum, rumput gajah dan daun - daunan. Sumber glukosa berasal dari cairan gula merah, gula pasir dan air kelapa, serta sumber mikroorganisme berasal dari kulit buah yang sudah busuk, terasi, keong mas dan nasi basi (Purwasasmita, 2009).

Menurut hasil penelitian Foidl et al., (2001), daun kelor digunakan sebagai MOL yang diujikan keberbagai tanaman seperti kacang tanah, kedelai dan jagung. Hasilnya sangat signifikan pada hasil panen tanaman yang diberi MOL daun kelor yaitu sebesar 20 - 35\% lebih besar dari pada hasil panen tanaman tanpa diberi MOL daun kelor, sedangkan hasil penelitian sebelumnya oleh Sriningsih (2014) tentang pemanfaatan kulit buah pisang dengan penambahan daun bambu (Emb) dan Em-4 sebagai MOL didapatkan hasil bahwa kandungan $\mathrm{N}$, P dan K MOL kulit pisang paling banyak dengan perlakuan bioaktivator EM-4 $125 \mathrm{ml}$. 


\section{Jurnal Agrotech 9 (1) 12-18}

Berdasarkan uraian di atas, maka dilakukan penelitian yang berjudul respons pemberian berbagai dosis mol daun kelor dengan penambahan kulit buah pisang terhadap pertumbuhan dan hasil tanaman jagung manis (Zea mays saccharata sturt.)

\section{Metode Penelitian}

Penelitian ini menggunakan Rancangan Acak Kelompok (RAK) satu faktor. Pengelompokan dilakukan berdasarkan arah datangnya sinar matahari dengan perlakuan berbagai dosis MOL daun kelor dengan penambahan kulit buah pisang. Perlakuan yang dicobakan terdiri dari 4 taraf yaitu :

$\mathrm{PM}_{0} \quad$ : Tanpa MOL (Kontrol)

$\mathrm{PM}_{1} \quad: 200 \mathrm{ml}+2$ liter air/ petak

$\mathrm{PM}_{2} \quad: 400 \mathrm{ml}+2$ liter air/ petak

$\mathrm{PM}_{3} \quad: 600 \mathrm{ml}+2$ liter air/ petak

Setiap perlakuan diulang sebanyak tiga kali, sehingga terdapat 12 petak percobaan. Untuk mengetahui pengaruh perlakuan yang dicobakan maka dilakukan analisis ragam dan bila hasil analisis tersebut menunjukkan pengaruh dilakukan dengan uji BNJ $\alpha=0,05$ untuk mengetahui perbedaan perlakuan.

\section{Pelaksanaan}

Pengelolaan Lahan

Persiapan lahan diawali pengukuran lokasi dan dilanjutkan dengan pengolahan tanah. Lahan dibajak sebanyak dua kali. Pembajakan pertama dilakukan untuk memudahkan pembersihan gulma dan didiamkan selama $3-5$ hari tujuannya agar gulma membusuk. Setelah didiamkan, dilakukan pembajakan kedua agar lahan betulbetul bersih dan diusahakan agar lahan tidak tergenang air. Bedengan dibuat dengan ukuran 2 $\mathrm{m} \times 3 \mathrm{~m}$ dan tinggi bedengan $20-30 \mathrm{~cm}$ dan jarak antar bedengan sebesar $50 \mathrm{~cm}$.

Pembuatan MOL Daun Kelor dengan Penambahan Kulit Buah Pisang

Proses yang dilakukan pertama-tama dalam pembutan MOL adalah sebagai berikut :

1. Ambil daun kelor yang sudah disiapkan sebanyak $3 \mathrm{~kg}$, lalu hacurkan daun tersebut dengan cara ditumbuk atau diblender.

2. Ambil kulit buah pisang sebanyak $1 \mathrm{~kg}$, lalu potong kecil - kecil memakai pisau.

3. Ambil daun kelor yang telah hancur dan kulit buah pisang, lalu masukkan ke dalam ember besar dan campurkan gula sebanyak $1 / 2 \mathrm{~kg}$ dan air cucian beras sebanyak 20 liter.
e-ISSN : 2621-7236

p-ISSN : 1858-134X

4. Setelah semuanya dimasukkan ke dalam ember, aduk campuran tersebut dengan kayu pengaduk agar semuanya tercampur rata.

5. Lalu tutup ember yang sudah berisi bahan tadi dengan menggunakan kantong plastik dan diikat dengan tali rafia.

6. Kemudian, didiamkan selama 2 minggu dan jangan lupa membuka tutup ember setiap pagi atau sore hari, ini gunanya agar gas yang ada di dalam bisa di keluarkan.

Aplikasi Perlakuan

Pengaplikasian MOL dilakukan tiga kali selama penanaman yang diaplikasihkan pada sore hari, MOL yang akan digunakan yaitu MOL daun kelor dengan penambahan kulit buah pisang. Sebelum diaplikasihkan, ukurlah MOL sesuai dengan setiap perlakuan dan ditambahkan air sebanyak 2 liter kedalam baskom. MOL yang sudah dicampurkan air dimasukkan kedalam gembor, lalu diaplikasihkan kebedengan sesuai perlakuan. Aplikasih pupuk dilakuakan pada tanaman berumur 7, 14 dan 21 HST.

\section{Penanaman}

Setelah bedengan percobaan telah siap, maka dilakukan penanaman. Penanaman benih jagung dilakukan dengan cara ditugal pada kedalaman $3-5 \mathrm{~cm}$. Setiap lubang ditanami dua biji benih dengan jarak tanam $25 \mathrm{~cm} \times 70 \mathrm{~cm}$. Setelah itu tutup dengan tanah, kemudian siram agar kelembaban tanah terjaga. Pada umur satu minggu setelah tanam dilakukan penjarangan dengan meninggalkan satu tanaman perumpun.

Pemeliharaan

Pemeliharaan tanaman meliputi, penyiraman, penyiangan, penyulaman, pembumbunan, pengendalian hama dan penyakit.

Penyiraman tanaman dilakukan pada pagi hari dengan menggunakan gembor. Adapun volume penyiraman disesuaikan dengan kondisi tanah, dengan tujuan untuk menghindari agar lahan tidak jenuh air sehingga dapat menyebabkan akar tanaman menjadi busuk. Penyiangan dilakukan dengan cara mencabut gulma/rerumputan yang tumbuh diarea pertanaman jagung dan dilakukan sesuai dengan kondisi pertumbuhan gulma. Penyulaman dilakukan pada saat tanaman berumur satu minggu setelah tanam, sedangkan tanaman sulaman diambil dari bedengan atau petakan yang khusus dipersiapkan sebagai tanaman sulaman bila terdapat benih jagung yang tidak tumbuh. Pembumbunan dilakukan pada saat tanaman berumur lima minggu setelah tanam 


\section{Jurnal agrotech 9 (1) 12-18}

dengan cara menimbun tanah pada pangkal batang setinggi $\pm 8 \mathrm{~cm}$. Hal tersebut dimaksudkan untuk menghindari kemungkinan terjadinya tanaman rebah. Pengendalian hama dan penyakit selama penelitian dilakukan dengan cara sanitasi lingkungan. Serangan yang sangat tinggi dimungkinkan untuk mengendalikan hama dan penyakit secara kimiawi.

Panen

Panen mudah dilakukan pada saat tongkol sudah mulai besar, klobot sudah mulai menguning dan rambut (bunga betina) sudah mulai mengering atau umur tanaman sudah mencapai 75 HST. Pemanenan dilakukan dengan cara memutar bagian tongkol lalu mencabut tongkol dari batangnya.

\section{Pengamatan}

1. Tinggi tanaman $(\mathrm{cm})$, diukur dari pangkal batang hingga daun terpanjang yang dilakukan pada umur 15, 30 dan 45 HST.

2. Jumlah daun (helai), diukur dengan cara menghitung semua daun yang terbentuk sempurna yang dilakukan pada umur 15, 30 dan 45 HST.

3. Panjang daun $(\mathrm{cm})$, diukur dengan cara mengukur daun terpanjang dan terbentuk sempurna yang dilakukan pada umur 15, 30 dan 45 HST.

4. Lingkar batang $(\mathrm{mm})$, mengukur diameter batang dilakukan pada umur 15, 30 dan 45 HST.

5. Umur berbunga (hari), diamati pada saat tanaman mulai berbunga

6. Panjang tongkol (cm), dengan cara mengukur panjang tongkol mulai dari pangkal hingga ujung tongkol pada saat panen.

7. Lingkar tongkol (mm), mengukur diameter tongkol dengan menggunakan mistar setelah panen.

8. Berat pertongkol ( $\mathrm{g} /$ tongkol), diukur dengan cara menimbang berat masing-masing tongkol.

9. Berat tongkol perpetak (kg/petak), dengan cara menimbang berat masing-masing buah tongkol petak.

10. Berat tongkol perhektar ( $\mathrm{t} / \mathrm{ha})$

\section{Hasil dan Pembahasan}

\section{Hasil}

Tinggi tanaman $(\mathrm{cm})$

Analisis ragam menunjukkan bahwa pemberian berbagai dosis Mol daun kelor dengan
e-ISSN : 2621-7236

p-ISSN : 1858-134X

penambahan kulit buah pisang berpengaruh nyata terhadap tinggi tanaman jagung manis pada umur 15, 30 dan 45 HST seperti disajikan pada Tabel 1 di bawah ini:

Tabel 1. Rata-rata tinggi tanaman jagung manis pada umur 15,30, 45 HST

\begin{tabular}{|c|c|c|c|}
\hline \multirow{2}{*}{$\begin{array}{c}\text { Perlakuan } \\
\text { Berbagai Dosis } \\
\text { Mol }\end{array}$} & \multicolumn{3}{|c|}{$\begin{array}{l}\text { Rata-rata tinggi tanaman } \\
\text { jagung manis (HST) }\end{array}$} \\
\hline & 15 & 30 & 45 \\
\hline $\begin{array}{l}\mathrm{PM}_{0} \text { (Kontrol) } \\
\mathrm{PM}_{1}(200 \mathrm{ml}+2\end{array}$ & $22,10^{b}$ & $36,36^{b}$ & $74,97^{b}$ \\
\hline $\begin{array}{l}\text { liter air) } \\
\mathrm{PM}_{2}(400 \mathrm{ml}+2\end{array}$ & $27,34^{\mathrm{a}}$ & $49,25^{\mathrm{a}}$ & $90,47^{\mathrm{a}}$ \\
\hline $\begin{array}{l}\text { liter air) } \\
\mathrm{PM}_{3}(600 \mathrm{ml}+2\end{array}$ & $27,57^{\mathrm{a}}$ & $49,31^{\mathrm{a}}$ & $91,37^{\mathrm{a}}$ \\
\hline liter air & $28,70^{\mathrm{a}}$ & $52,15^{\mathrm{a}}$ & $96,28^{a}$ \\
\hline BNJ $\alpha=0,05$ & 5,11 & 11,71 & 15,12 \\
\hline
\end{tabular}

Ket : Angka yang diikuti dengan huruf yang sama pada kolom yang sama menunjukkan pengaruh berbeda tidak nyata pada taraf uji BNJ $\alpha=0,05$

Hasil uji BNJ $\alpha=0,05$ menunjukkan bahwa perlakuan berbagai dosis Mol daun kelor dengan penambahan kulit buah pisang memberikan pengaruh lebih baik terhadap tinggi tanaman jagung manis pada umur 15,30 dan 45 HST dan berbeda nyata dengan perlakuan tanpa $\mathrm{Mol}\left(\mathrm{PM}_{0}\right)$.

Jumlah daun (helai)

Hasil pengamatan jumlah daun tanaman jagung manis pada umur 15,30 dan 45 HST,dapat dilihat pada Tabel lampiran 4a, 5a dan $6 \mathrm{a}$, sedangkan analisis ragamnya dapat dilihat pada Tabel lampiran 4b, 5b da 6b. Analisis ragam menunjukkan bahwa pemberian berbagai dosis Mol daun kelor dengan penambahan kulit buah pisang tidak berpengaruh nyata terhadap jumlah daun tanaman jagung manis pada umur 15,30 dan 45 HST seperti disajikan pada Gambar 1.

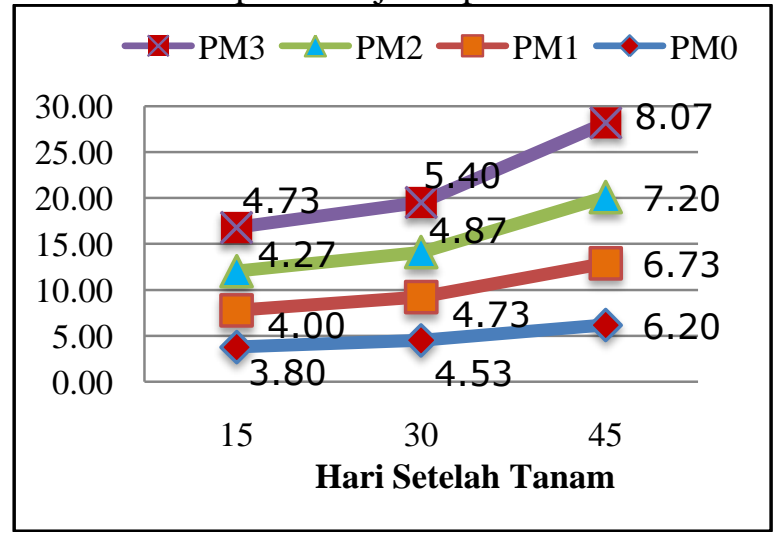

Gambar 1. Rata-rata jumlah daun tanaman jagung manis saat umur 15, 30 dan 45 HST. 


\section{Jurnal Ogrotech 9 (1) 12-18}

Berdasarkan Gambar 1 menunjukkan bahwa rata-rata jumlah daun tertinggi pada tanaman jagung manis pada umur 15, 30 dan 45 HST diperoleh pada perlakuan $\mathrm{PM}_{3}$ ( dosis 600 $\mathrm{ml}+2$ liter air) yaitu 4,73, 5,40 dan 8,07, sedangakan rata-rata terendah diperoleh pada perlakuan $\mathrm{PM}_{0}$ (Tanpa Mol).

Panjang daun $(\mathrm{cm})$

Analisis ragam menunjukkan bahwa pemberian berbagai dosis Mol daun kelor dengan penambahan kulit buah pisang berpengaruh nyata terhadap panjang daun tanaman jagung manis pada umur 15, 30 dan 45 HST seperti disajikan pada Tabel 2.

\begin{tabular}{lccc}
\hline \multicolumn{1}{c}{$\begin{array}{c}\text { Perlakuan } \\
\text { Berbagai Dosis } \\
\text { Mol }\end{array}$} & \multicolumn{3}{c}{$\begin{array}{c}\text { Rata-rata panajang daun } \\
\text { tanaman jagung manis }\end{array}$} \\
\cline { 2 - 4 } & $\begin{array}{c}15 \\
\mathrm{HST}\end{array}$ & $\begin{array}{c}\text { HST } \\
\text { HST }\end{array}$ & $\begin{array}{c}45 \\
\mathrm{HST}\end{array}$ \\
\hline $\mathrm{PM}_{0}$ (Kontrol) & $15,19^{\mathrm{b}}$ & $27,49^{\mathrm{b}}$ & $50,19^{\mathrm{b}}$ \\
$\mathrm{PM}_{1}(200 \mathrm{ml}+2$ & & & \\
liter air) & $19,10^{\text {a }}$ & $38,97^{\text {a }}$ & $63,63^{\text {a }}$ \\
$\mathrm{PM}_{2}(400 \mathrm{ml}+2$ & & & \\
liter air) & $19,43^{\text {a }}$ & $39,02^{\text {a }}$ & $63,91^{\text {a }}$ \\
$\mathrm{PM}_{3}(600 \mathrm{ml}+2$ & & & \\
liter air & $20,14^{\text {a }}$ & $41,07^{\text {a }}$ & $67,32^{\text {a }}$ \\
\hline BNJ $\alpha=0,05$ & 3,80 & 9,79 & 12,31 \\
\hline
\end{tabular}

Ket : Angka yang diikuti dengan huruf yang sama pada kolom yang sama menunjukkan pengaruh berbeda tidak nyata pada taraf uji BNJ $\alpha=0,05$

Hasil uji BNJ $\alpha=0,05$ menunjukkan bahwa perlakuan berbagai dosis Mol daun kelor dengan penambahan kulit buah pisang memberikan pengaruh lebih baik terhadap tinggi panjang daun tanaman jagung manis pada umur 15, 30 dan 45 HST dan berbeda nyata dengan perlakuan tanpa $\mathrm{Mol}\left(\mathrm{PM}_{0}\right)$.

Lingkar batang $(\mathrm{mm})$

Analisis ragam menunjukkan bahwa pemberian berbagai dosis Mol daun kelor dengan penambahan kulit buah pisang berpengaruh tidak nyata terhadap lingkar batang tanaman jagung manis pada umur 15, 30 dan 45 HST seperti disajikan pada Gambar 2.

Berdasarkan Gambar 2 menunjukkan bahwa rata-rata lingkar batang tertinggi pada tanaman jagung manis pada umur 15, 30 dan 45 HST diperoleh pada perlakuan $\mathrm{PM}_{3}$ ( dosis 600 $\mathrm{ml}+2$ liter air) yaitu 8,53, 14,00 dan 19,62, sedangakan rata-rata terendah diperoleh pada perlakuan $\mathrm{PM}_{0}$ (Tanpa Mol).
e-ISSN : 2621-7236

p-ISSN : 1858-134X

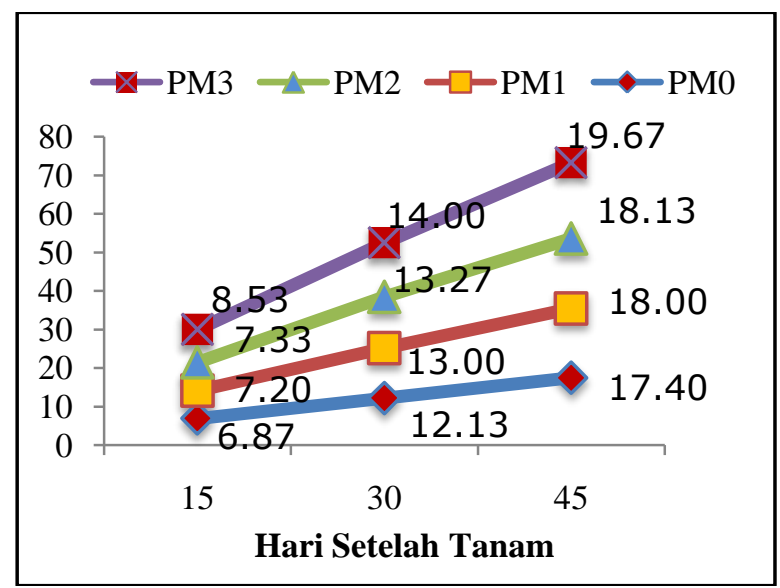

Gambar 2. Rata-rata lingkar batang tanaman jagung manis saat umur 15, 30 dan 45 HST

Umur berbunga (hari)

Analisis ragam menunjukkan bahwa pemberian berbagai dosis Mol daun kelor dengan penambahan kulit buah pisang berpengaruh tidak nyata terhadap lingkar batang tanaman jagung manis seperti disajikan pada Gambar 3.

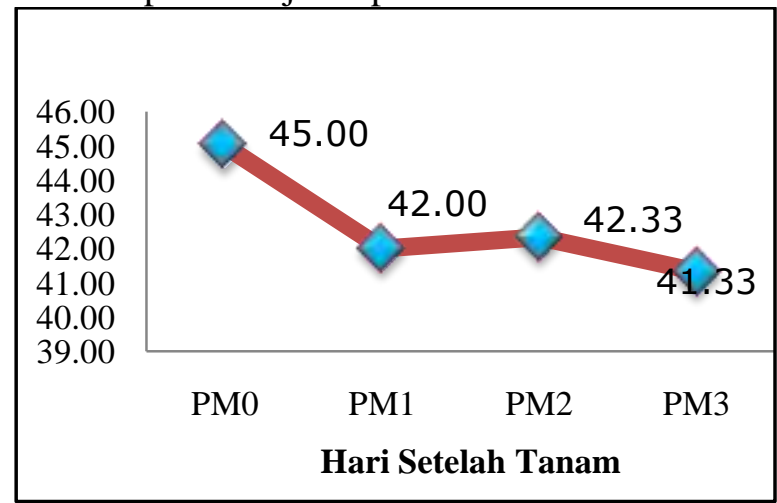

Gambar 3. Rata-rata umur berbunga tanaman jagung manis.

Berdasarkan Gambar 3 menunjukkan bahwa rata-rata umur berbunga pada tanaman jagung manis paling cepat diperoleh pada perlakuan $\mathrm{PM}_{3}$ ( dosis $600 \mathrm{ml}+2$ liter air) yaitu 41,33, sedangakan yang terlambat diperoleh pada perlakuan $\mathrm{PM}_{0}$ (Tanpa Mol) yaitu 45,00.

Panjang tongkol $(\mathrm{cm})$

Hasil pengamatan panjang tongkol tanaman jagung manis saat panen, dapat dilihat pada Tabel lampiran 14a, sedangkan analisis ragamnya dapat dilihat pada Tabel lampiran 14b. Analisis ragam menunjukkan bahwa pemberian berbagai dosis Mol daun kelor dengan penambahan kulit buah pisang berpengaruh tidak nyata terhadap panjang tongkol tanaman jagung manis seperti disajikan pada Gambar 4. 
Jurnal Ogrotech 9 (1) 12-18

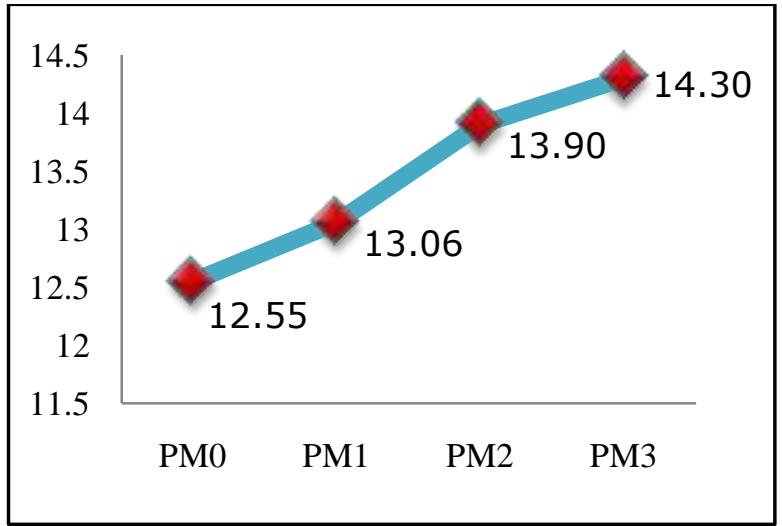

Gambar 4. Rata-rata panjang tongkol tanaman jagung manis saat panen.

Berdasarkan Gambar 4 menunjukkan bahwa rata-rata panjang tongkol tanaman jagung manis yang terpanjang diperoleh pada perlakuan $\mathrm{PM}_{3}$ ( dosis $600 \mathrm{ml}+2$ liter air) yaitu 14,30, sedangakan yang terpendek diperoleh pada perlakuan $\mathrm{PM}_{0}$ (Tanpa Mol) yaitu 12,55.

\section{Lingkar tongkol (mm)}

Analisis ragam menunjukkan bahwa pemberian berbagai dosis Mol daun kelor dengan penambahan kulit buah pisang berpengaruh tidak nyata terhadap panjang tongkol tanaman jagung manis seperti disajikan pada Gambar 5.

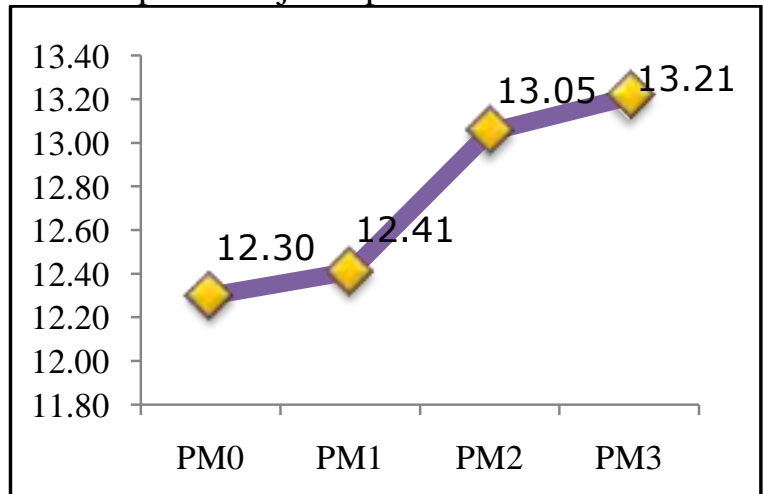

Gambar 5. Rata-rata lingkar tongkol tanaman jagung manis saat panen.

Berdasarkan Gambar 5 menunjukkan bahwa rata-rata lingkar tongkol tanaman jagung manis yang tertinggi diperoleh pada perlakuan $\mathrm{PM}_{3}$ ( dosis $600 \mathrm{ml}+2$ liter air) yaitu 13,21, sedangakan yang terendah diperoleh pada perlakuan $\mathrm{PM}_{0}$ (Tanpa Mol) yaitu 12,30

Berat pertongkol (g)

Analisis ragam menunjukkan bahwa pemberian berbagai dosis Mol daun kelor dengan penambahan kulit buah pisang berpengaruh tidak nyata terhadap berat tongkol tanaman jagung manis seperti disajikan pada Gambar 6.
e-ISSN : 2621-7236

p-ISSN : 1858-134X

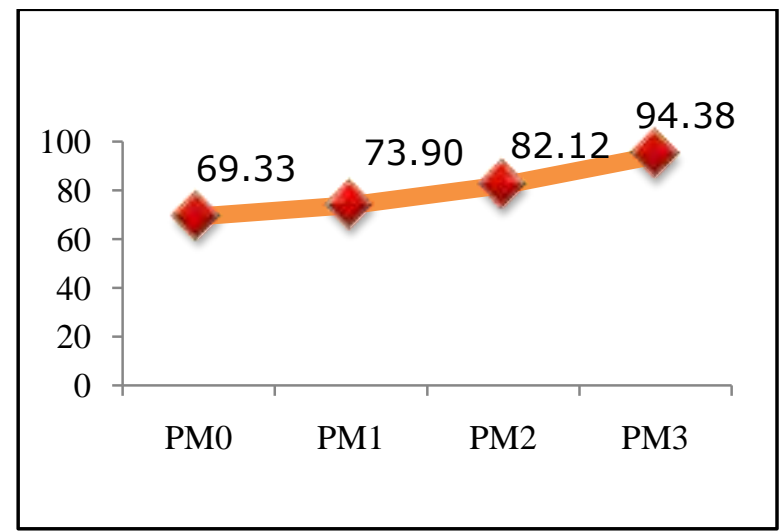

Gambar 6. Rata-rata berat tongkol (g) tanaman jagung manis saat panen.

Berdasarkan Gambar 6 menunjukkan bahwa rata-rata berat tongkol tanaman jagung manis yang tertinggi diperoleh pada perlakuan $\mathrm{PM}_{3}$ ( dosis $600 \mathrm{ml}+2$ liter air) yaitu 94,38, sedangakan yang terendah diperoleh pada perlakuan $\mathrm{PM}_{0}$ (Tanpa Mol) yaitu 69,33.

Berat tongkol per petak $(\mathrm{kg})$ dan berat tongkol per hektar (t)

Analisis ragam menunjukkan bahwa pemberian berbagai dosis Mol daun kelor dengan penambahan kulit buah pisang berpengaruh tidak nyata terhadap berat tongkol per petak dan per hektar tanaman jagung manis seperti disajikan pada Gambar 7.

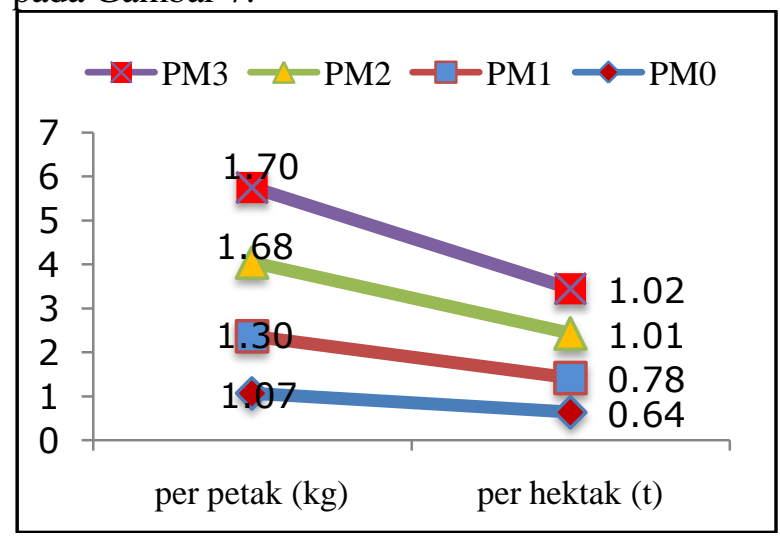

Gambar 7. Rata-rata berat tongkol per petak $(\mathrm{kg})$ dan per hektar $(\mathrm{t})$ tanaman jagung manis saat panen.

Berdasarkan Gambar 7 menunjukkan bahwa rata-rata berat tongkol per petak dan per hektar tanaman jagung manis yang tertinggi diperoleh pada perlakuan $\mathrm{PM}_{3}$ ( dosis $600 \mathrm{ml}+2$ liter air) yaitu 1,70 ( $\mathrm{kg}$ ) dan 1,02 (t), sedangakan yang terendah diperoleh pada perlakuan $\mathrm{PM}_{0}$ (Tanpa Mol) yaitu 1,07 (kg) dan 0,64 (t).

\section{Pembahasan}

Hasil penelitian menunjukkan bahwa perlakuan berbagai dosis Mol daun kelor dengan penambahan kulit buah pisang tidak berpengaruh 


\section{Jurnal Ogrotech 9 (1) 12-18}

nyata terhadap jumlah daun, lingkar batang, umur berbunga, panjang tongkol, lingkar tongkol, berat tongkol per tongkol $(\mathrm{g})$, per petak $(\mathrm{kg})$ dan per hektar (t) pada tanaman jagung manis. Hal ini sesuai dengan sifat pupuk organik yang diduga bahwa unsur hara yang terkandung dalam pupuk organik yang diberikan tersebut belum mampu diserap secara maksimal oleh tanaman sebab belum terurai dengan baik di dalam tanah, sehingga tanaman akan lambat pula pertumbuhannya dan penyebab lain dari lambatnya pertumbuhan tanaman dalam penelitian ini yaitu tanah tempat penelitian memiliki tekstur keras, tanah yang digunakan tidak pernah mendapatkan bahan organik sehingga unsur hara dalam tanah tidak tercukupi dan faktor lingkungan yang tidak mendukung seperti suhu udara, cahaya dan kelembaban. Menurut Wangiana $d k k$., (2009), menambahkan bahan organik memberikan respon yang lambat terhadap tanaman dikarenakan tanah tempat penelitian mempunyai C-organik kategori rendah.

Berdasarkan hasil penelitian menunjukkan bahwa tinggi tanaman dan panjang daun tanaman jagung manis pada umur 15,30 dan 45 HST dalam perlakuan berbagai dosis Mol daun kelor dengan penambahan kulit buah pisang yaitu $\mathrm{PM}_{1}$, $\mathrm{PM}_{2}$ dan $\mathrm{PM}_{3}$ berbeda nyata dengan perlakuan $\mathrm{PM}_{0}$ (kontrol). Hal ini menunjukkan bahwa perlakuan berbagai dosis Mol memiliki unsur hara $\mathrm{N}$ (nitrogen) yang lebih tinggi dan mengandung jenis hormon sitokinin yang dapat meningkatkan petumbuhan tanaman seperti tinggi tanaman dan panjang daun.

Mol daun kelor dengan penambahan kulit buah pisang mengandung $\mathrm{N}$ dan $\mathrm{P}$ yang agak berimbang, hal ini sangat baik untuk pertumbuhan vegetatif tanaman karena mengandung karbohidrat yang terdapat pada pada air cucian beras, glukosa dari gula pasir dan kulit buah pisang sebagai sumber mikroorganisme. Menurut Lingga \& Marsono (2000) bahwa peran utama Nitrogen bagi tanaman adalah merangsang pertumbuhan secara keseluruhan, khususnya batang, daun dan tunas.

\section{Kesimpulan dan Saran}

\section{Kesimpulan}

Berdasarkan hasil penelitian dapat disimpulkan bahwa perlakuan berbagai dosis Mol daun kelor dengan penambahan kulit buah pisang $\mathrm{PM}_{3}$ dengan dosis $600 \mathrm{ml}+2$ liter air memberikan pengaruh lebih baik terhadap tinggi tanaman dan panjang daun jagung manis.
e-ISSN : 2621-7236

p-ISSN : 1858-134X

\section{Saran}

Disarankan bahwa perlu dilakukan penelitian lanjut tentang penggunaan Mol daun Kelor dengan penambahan kulit buah pisang dengan dosis yang lebih tinggi.

\section{Daftar Pustaka}

Agitarani, 2011. Morfologi Tanaman Jagung. Depertemen Botani Fakultas Pertanian IPB Bogor.

Foidl, N., Makkar H.P.S. and Becker K, 2001. "The Potential Of Moringa Oleifera For Agricultural And Industrial Uses". Journal of development potential for Moringa products. November 2001. P 6-8.

Harahap, 2007. Morfologi Tanaman Jagung. Depertemen Botani Fakultas Pertanian IPB Bogor.

Herniwati dan Basir Nappu, 2011. Peran dan Pemanfaatan Mikroorganisme Lokal (MOL) Mendukung Pertanian Organik.

Lingga P., dan Marsono, 2002. Petunjuk penggunaan pupuk. Edisi Revisi. Penebar Swadaya. Jakarta

Putri, Habrina Ananda, 2011. Pengaruh Pemberian Beberapa Konsentrasi Pupuk Organik Cair Lengkap (POCL) Bio Sugih Terhadap Pertumbuhan dan Hasil Tanaman Jagung Manis. Skripsi. Universitas Andalas Padang.

Purwasasmita M, Kurnia K. 2009. Mikroorganisme Lokal sebagai Pemicu Siklus Kehidupan dalam Bioreaktor Tanaman. Seminar Nasional Teknik Kimia Indonesia- SNTKI 2009. Bandung 19-20 Oktober 2009

Sriningsih, Endang. 2014. Pemanfaatan Kulit Buah Pisang (Musa paradisiaca L.) Dengan Penambahan Daun Bambu (Emb) Dan Em-4 Sebagai Pupuk Cair. Skripsi thesis, Universitas Muhammadiyah Surakarta.

Wagiana W., Hanan M. dan Ngawit I.K., 2009. Peningkatan Hasil Jagung Hibrida Varietas BISI-2 dengan Aplikasi Pupuk Organik. Fakultas Pertanian Mataram. Mataram. 